\title{
Development of Measures to Improve the Efficiency of Using Pulverized Coal in Blast Furnace Smelting
}

\section{Michail Polovets ${ }^{1}$, Konstantin Mironov², Sergei Zagainov¹, and Boris Tleugabulov ${ }^{1}$}

${ }^{1}$ Ural Federal University (UrFU), Ekaterinburg, Russia

${ }^{2}$ JSC "EVRAZ NTMK," Nizhniy Tagil, Russia

\section{Abstract}

Efficiency of using of pulverized coal injection ( $\mathrm{PCl}$ ) in blast furnace smelting depends directly on its cost price. For the preparation of $\mathrm{PCl}$ at Russian enterprises, mainly non-coking lean and gas coals of Kuzbass are used, which does not provide the

Corresponding Author:

Michail Polovets

querti25@gmail.com

Received: 6 June 2018

Accepted: 15 June 2018

Published: 17 July 2018

Publishing services provided by Knowledge $\mathrm{E}$

(c) Michail Polovets et al. This article is distributed under the terms of the Creative Commons Attribution License, which permits unrestricted use and redistribution provided that the original author and source are credited.

Selection and Peer-review under the responsibility of the TIM'2018 Conference Committee.

\section{G OPEN ACCESS} desired reduction in costs for the production of cast-iron for JSC EVRAZ NTMK and PJSC NLMK due to high transportation costs. In this connection, the possibility of using petroleum coke and coke dust in the composition of pulverized coal for blast furnace smelting had been analyzed. Main obstacle to the use of petroleum coke is its high sulfur content. Optimal proportion of the petroleum coke in the composition of the $\mathrm{PCl}$ is determined, depending on the total consumption of $\mathrm{PCl}$ and the sulfur content in it. Experimental-industrial tests were conducted to introduce coke dust from the dry coke quenching plant into the charge of pulverized-coal fuel. Totally, petcoke and coke dust can replace up to $25 \%$ of imported coal and reduce fuel costs by $4-5 \%$.

Keywords: blast furnace, pulverized coal injection ( $\mathrm{PCl}$ ), coke dust, petroleum coke (petcoke), sinter

\section{Introduction}

Usage of pulverized coal $(\mathrm{PCl})$ in blast furnace smelting is a promising direction to reduce costs for the production of cast-iron and is becoming increasingly widespread [1-4]. Two main indicators determine economic efficiency of using the PCl: substitution rate and the cost of the PCl. Coefficient of replacement of coke with pulverized coal, in turn, depends on the composition of the coal mixture (ash content, sulfur content, volatiles) and the completeness of combustion of coal particles within the tuyere focus [3]. Significantly, greater impact on economic efficiency of using the PCl is its cost [4], 
which consists of the purchase cost of raw materials (coals), transportation costs and the cost of preparing the $\mathrm{PCl}$.

For the production of $\mathrm{PCl}$ often use low-ash coals, typically a mixture of $2-3$ coal types [5]. For the preparation of $\mathrm{PCl}$ at Russian enterprises, mainly non-coking lean and gas coals of Kuzbass are used. This makes it possible to increase the proportions of coking coal in the composition of coke charge and improve the quality of coke while maintaining the volume of supplies, but does not provide the desired reduction in costs for the production of cast iron, because when blowing PUT, not only coke but also cheap natural gas is replaced. This is especially true for JSC 'EVRAZ NTMK' and PJSC 'NLMK', for which the transport component in the cost of $\mathrm{PCl}$ reaches $25-30 \%$. In this regard, there is a need to work on the issue of partial replacement of coal with alternative, less expensive carbon-containing materials. An additional criterion for choosing such materials is the relative (in comparison with Kuzbass) proximity of their production. In this article, the possibility of using petroleum coke and coke dust in the composition of pulverized coal for blast furnace smelting is analyzed.

Petroleum coke is produced with delayed coking (from 24 to 40 hours), mainly heavy fractions of primary oil refining obtained in atmospheric vacuum distillation units, and cracking residues of secondary thermal processes of oil refining [6, 7]. Quality of the petroleum coke is characterized by low ash content (up to 1\%), moderate volatile content (from 9 to 15\%), high sulfur content (from 1.3 to 4.5\%). Low ash content of the petroleum coke causes a high content of non-volatile carbon (at the level of 85-90\%) and high calorific value of its combustion ( $8000 \mathrm{kcal} / \mathrm{kg})$. Petroleum coke in Russia is producing at nine plants [8]. Mail volume $(65-70 \%)$ of the produced petroleum coke is consuming by aluminum plants for making electrodes. The rest of the petroleum coke (reduced quality) is used as fuel and has a low cost.

The largest petrocoke producers are located in the Irkutsk, Volgograd, Samara, Perm, Omsk regions, and in the Republic of Bashkortostan. Proceeding from the principle of territorial proximity, it is preferable for PJSC 'NLMK' to receive such a product from Volgograd or Samara region, for JSC 'EVRAZ NTMK' - from Perm or Ufa. When replacing part of the coals with petrocoke from Volgograd, the reduction of transportation costs for PJSC 'NLMK' will be about 1500 rubles/ton. The maximum decrease in transportation costs for JSC EVRAZ NTMK - about 1000 rubles/ton - will be with the use of a petroleum coke from Perm. In Perm petcoke compared with Bashkir significantly less sulfur content ( $2.5 \%$ versus $3.85 \%$ ).

The main obstacle of using petroleum coke is its high sulfur content. However, there are known methods of desulfurization of the petroleum coke [7], allowing to remove 
about $50 \%$ of sulfur from it. One of the main ways to remove sulfur is hydrogenation, which is described by the reaction:

$$
\mathrm{S}+\mathrm{H}_{2} \mathrm{O}+\mathrm{C}=\mathrm{H}_{2} \mathrm{~S}+\mathrm{CO} \text {. }
$$

As can be seen from this reaction, 12 units of carbon are required for 32 units of sulfur mass to be removed. The calculated composition of the desulfurized petrocoke in comparison with the composition of the initial petrocoke, as well as the quality of the PCl used at JSC 'EVRAZ NTMK' is presented in Table 1.

TABLE 1: Quality of fuel for blast furnace smelting.

\begin{tabular}{|l|c|c|c|c|}
\hline Type of fuel & A (ash), \% & V(volat.), $\%$ & S, \% & C, \% \\
\hline PCI & 7,93 & 18,07 & 0,36 & 74,0 \\
\hline petrocoke 1 (initial) & 0,94 & 9,5 & 2,56 & 87,0 \\
\hline petrocoke 2 (Desulfurization) & 0,98 & 8,27 & 1,32 & 89,43 \\
\hline
\end{tabular}

Calculations of blast furnace smelting parameters were carried out for the conditions of the blast furnace shop of JSC 'EVRAZ NTMK' at a flow rate of $100 \mathrm{~kg} /$ ton and 70 $\mathrm{m}^{3} /$ ton of natural gas consumption [9]. In the course of the calculations, the specific costs of the components of the charge, the slag yield, the chemical compositions of the smelting products, the performance of the furnaces and the cost of the cast iron were determined. In the case of the use of a desulfurized petrocoke, the cost of desulfurization is taken into account for $20 \%$ of its cost.

Calculation results showed that with an increase in the share of the oil coke in the $\mathrm{PCl}$, from o to $30 \%$, fuel costs, which include the sum of unit costs for coke, natural gas and $\mathrm{PCl}$, are reduced by more than $3 \%$ (Figure 1 ). It should be noted that, despite the rise in price of petroleum coke 2 for the desulfurization operation, the difference in fuel costs is not significant. This is explained by an increase in the coefficient of replacement of coke.

Nevertheless, as the share of the petrocoke increases, the content of sulfur in cast iron increases steadily (Figure 2).

To ensure compliance with the standard of the enterprise for the sulfur content in cast iron, the optimum petrocoke consumption was determined depending on the sulfur content in it (Figure 3).

Comparing Figures 1 and 3, it can be noted that the use of the original petrocoke 1 $(2.56 \% \mathrm{~S})$ is limited to $10 \%$ in the composition of the $\mathrm{PCl}$ at a total flow rate of 100 $\mathrm{kg} /$ ton of cast iron. This allows reducing the total cost of fuel by only $1.3 \%$. Preliminary desulfurization of the petrocoke allows it to increase its consumption to $23 \%$ in the 


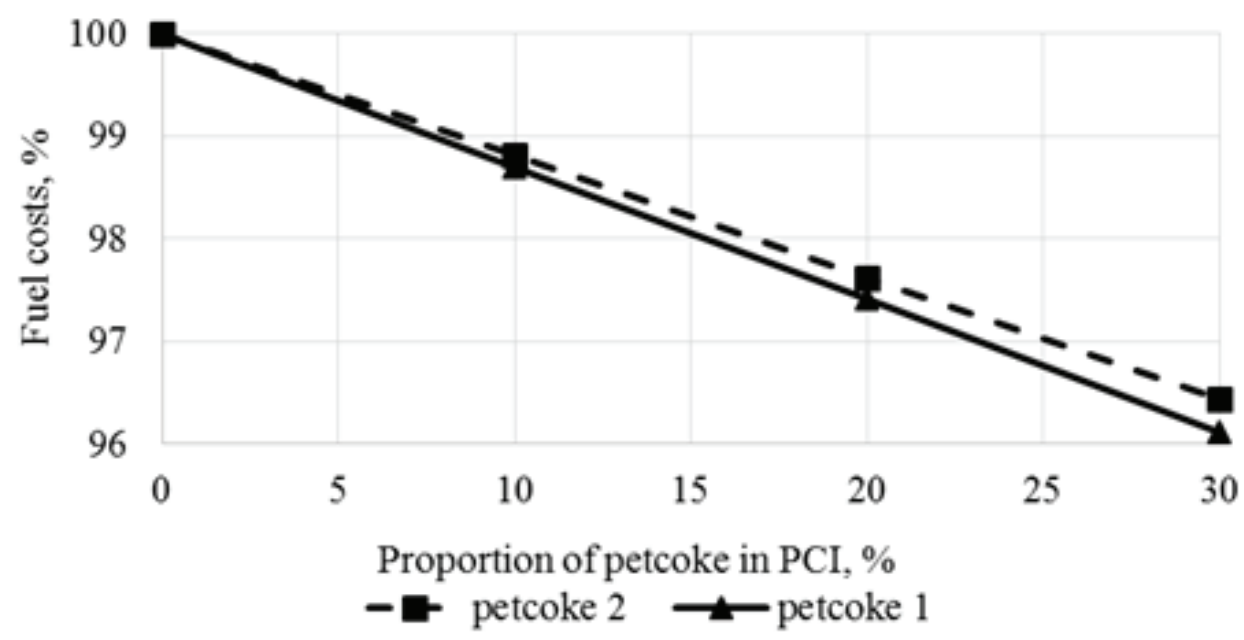

Figure 1: Influence of the proportion of the oil coke in the composition of the $\mathrm{PCl}$ on the relative costs of fuel..

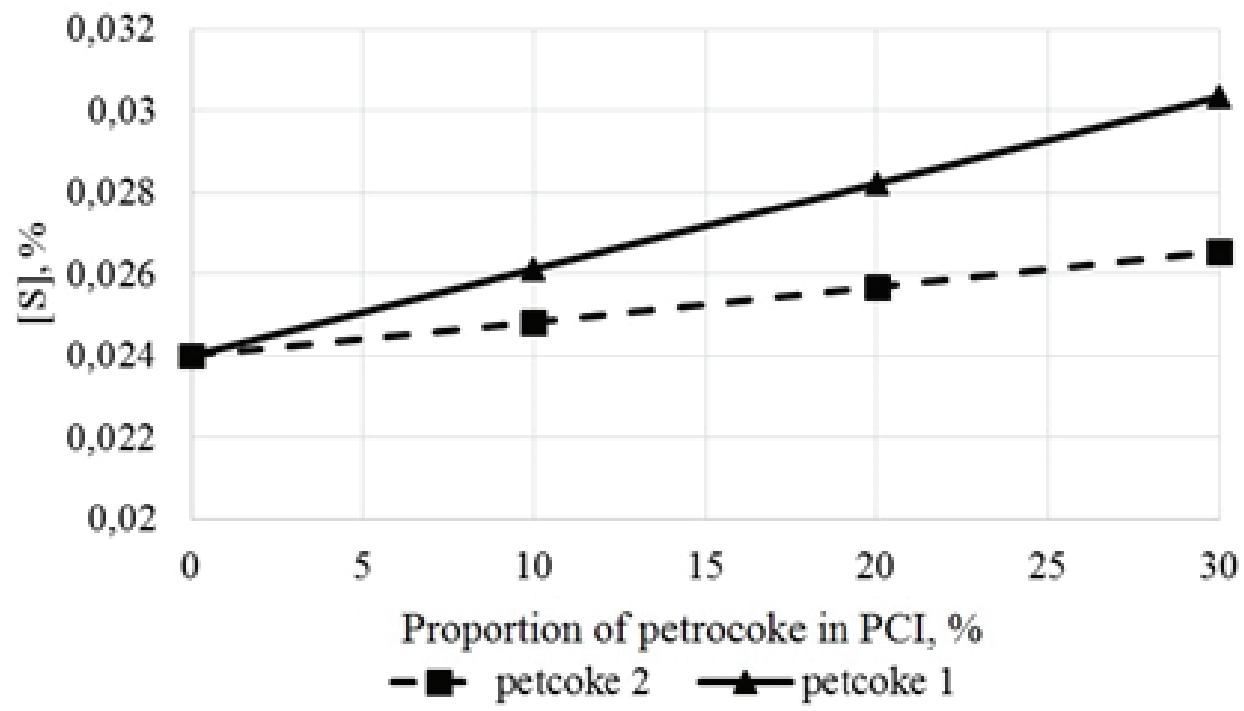

Figure 2: Influence of proportion of petroleum coke in the composition of $\mathrm{PCl}$ on sulfur content in cast iron.

$\mathrm{PCl}$, which reduces (despite the additional costs) the total fuel costs by $3 \%$. Thus, the preliminary desulfurization of the petroleum coke should be considered expedient.

An additional measure to reduce the cost of pulverized coal is the use of a dry coke quenching plant (DCQP) in the charge for its preparation of coke dust. The quality of the coke dust differs from the coals used with an increased ash content, a much lower volatiles yield and comparable sulfur content (in terms of solid residue). The melting point of the ash of coke dust is significantly lower than that of energy coals.

Calorific value or heat of combustion of coke dust is approximately $1000 \mathrm{kcal} / \mathrm{kg}$ below any coal grades. However, this indicator does not reflect the actual heat transfer of carbon-containing materials in blast furnace smelting. The heat of combustion 


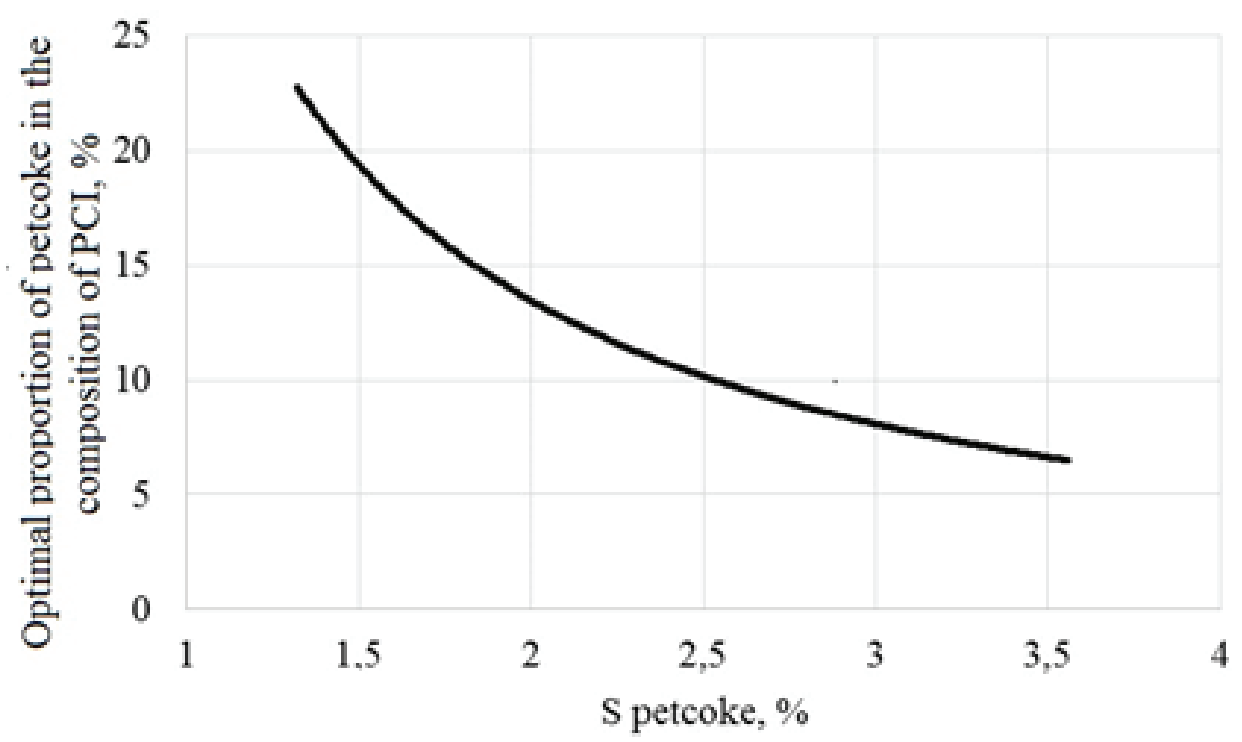

Figure 3: Influence of S content in the petrocoke on its optimal proportion in the composition of $\mathrm{PCI}$.

characterizes the release of heat from complete combustion reactions. A significant contribution to this value is made by the reactions of oxidation of hydrogen and saturated hydrocarbons, the total content of which in volatiles is more than $80 \%$. Volatile is more than $0.3 \mathrm{~m}^{3} / \mathrm{kg}$ of coal, and with the reforming of hydrocarbons - more than 0.5 $\mathrm{m}^{3} / \mathrm{kg}$ of carbon in their content $14-15 \%$ of the original weight. In the same smelting blast coal gasification reactions occur at the incomplete combustion of methane and hydrogen, not only do not contribute heat, but also require substantial expansion on heating and energy costs. The results of calculating the actual heat transfer values of $\mathrm{PCl}$ with a different fraction of coke dust are shown in Figure 4.

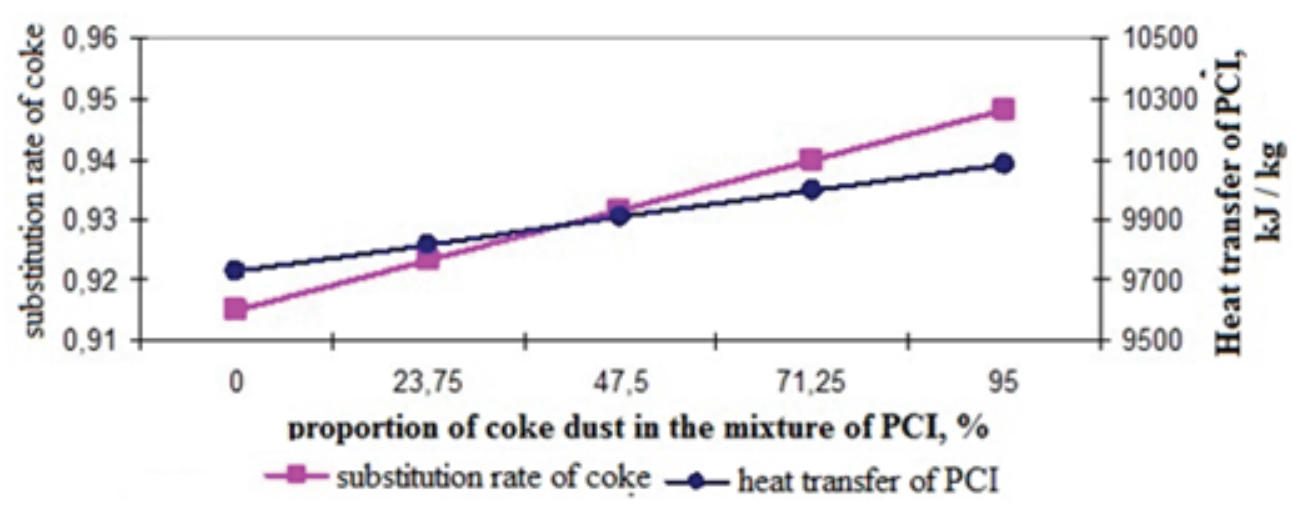

Figure 4: Influence of the proportion of coke dust in the charge of $\mathrm{PCl}$ on the heat transfer of $\mathrm{PCl}$ and the substitution rate of coke.

Based on this preliminary analysis, pilot-industrial tests were conducted to introduce coke dust from the dry coke quenching plant as a component of the charge of pulverized-coal fuel. The proportions of DCQP dust in the mixture with coal during the 
test period was $2.5-3 \%$. According to the results of pilot industrial tests, conclusions were reached on the principle possibility of using DCQP dust in the PCI charge, as there have been no significant changes in the operation of blast furnaces, and the cost of fuel and fuel costs in blast furnace smelting has significantly decreased.

\section{Summary}

The expediency of using petrocoke and coke dust in the charge for the preparation of $\mathrm{PCl}$ is substantiated. Efficiency of using the petroleum coke is increased by preliminary desulfurization. Totally petrocoke and coke dust can replace up to $25 \%$ of imported coal and reduce fuel costs by $4-5 \%$.

\section{References}

[1] Toxopeus, H., Steeghs, A., and van den Boer, J. (2001). PCl at the start of the 21st century, in 60th Ironmaking Conference Proceedings, vol. 60, pp. 736-742. Baltimore, USA.

[2] Filippov, V. V., Mikhalev, V. A., Mironov, K. V., et al. (2017). The development of the theory and technology for smelting the vanadium-containing cast iron with the use of the pulverized coal fuel. Byulleten Nouchno-tekhnichrskoy i Ekonomicheskoy Informatsii "Chernaya metallurgiya", vol. 1408, pp. 22-26.

[3] Filippov, V. V., Mikhalev, V. A., Mironov, K. V., et al. (2017). The advantages and risks of the technology for the blast furnace heat with the use of the pulverized coal. Byulleten Nauchno-Tekhnichrskoy i Ekonomicheskoy Informatsii "Chernaya metallurgiya", vol. 1405, pp. 38-42.

[4] Smirnov, L. A., Tleugabulov, B. S., Zagainov, S. A., et al. (2016). Some theoretical aspects of the technology for the joint injection of the natural gas and pulverized coal. Byulleten Nauchno-Tekhnichrskoy i Ekonomicheskoy Informatsii "Chernayo metallurgiya", vol. 1397, pp. 19-22.

[5] Geerdes, M., Toxopeus, H., van der Vliet, C., et al. (2009). Modern Blast Furnace Ironmaking: An Introduction. Amsterdam: IOS Press.

[6] Syunyaev, Z. I. (1973). Production, Upclassing and Use of Petroleum Coke. Moscow: Chemistry.

[7] Al-Haj-Ibrahim, H. (1990). Desulfurization of petroleum coke, Research report. Pittsburgh: University of Pittsburgh.

[8] Retrieved from http://www.infomine.ru 
[9] Kushnarev, A. V., Filippov, V. V., Mikhalev, V. A., et al. (2017). System improvement of vanadium hot metal process at EVRAZ NTMK. CIS Iron and Steel Review, vol. 13, pp. 13-17. 